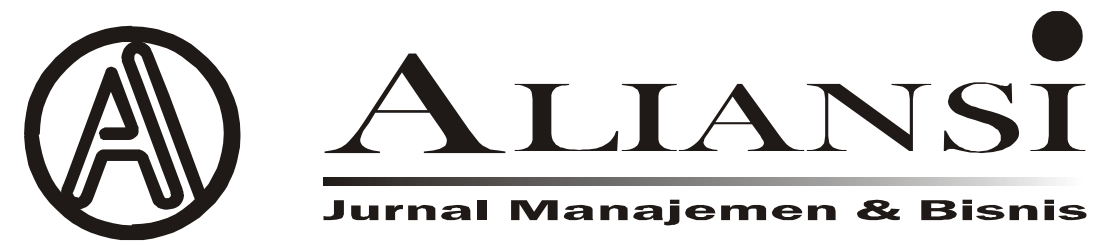

\title{
ANALISIS KEMANDIRIAN DAN KEMAMPUAN KEUANGAN DAERAH TERHADAP KEMISKINAN DI KABUPATEN BOGOR
}

\author{
Oleh : Milda Handayani*, Rycha Kuwara Sari*, Ari Sulistyowati*
}

email : milda.handayani@ubharajaya.ac.id

\begin{abstract}
The regional government holds the mandate of the central government in implementing regional autonomy and has a role in resource management which in turn can improve the welfare of the community. To be able to improve the welfare of the community, one measure can use an analysis of regional financial independence and regional financial capacity by assessing the original regional income compared to total regional income and the balance fund. And see the effect on the percentage of poor. The results obtained, the regional financial independence of Bogor Regency is still in the range of 0\% - 25\% so that it is categorized as very low, while the regional financial capacity is at $24.07 \%$ or it can be said that it is sufficient. Meanwhile, the results of multiple linear regressions for regional financial independence and regional financial capacity have an influence on the percentage of poor people. The expected result is that Bogor Regency can do more to increase its base of tax and retribution revenues so as to minimize budget dependence from the central government and local governments.
\end{abstract}

Keywords: regional financial independence, regional financial capacity, poverty

\section{PENDAHULUAN}

Otonomi daerah merupakan kondisi dengan melihat kemampuan daerah melalui fungsi pemerintahan yang cepat, dekat dan tepat sehingga manajemen pemerintahan dapat tertata dengan responsive, akuntabel, transparan dan efisien sesuai dengan kebutuhan masyarakat (Woestho et al., 2020)

Pemerintah daerah yang merupakan pemegang mandat pemerintah pusat dalam melaksanakan otonomi daerah mempunyai peranan terhadap pengelolaan sumber daya yang pada akhirnya dapat meningkatkan kesejahteraan masyarakat.

Otonomi daerah telah diatur dalam Undang Undang Nomor 23 Tahun 2014 tentang Pemerintahan Daerah, dimana tujuannya menata manajemen pemerintah daerah sehingga berjalan secara responsive, akuntabel, transparan serta efisien dengan mengedepankan kondisi serta kemampuan daerah.

Menurut (Kamaroellah, 2017), ada empat elemen penting yang diserahkan pemerintah pusat kepada pemerintah daerah dalam pelaksanaan otonomi daerah, yaitu desentralisasi politik, derajat desentralisasi, desentralisasi administrasi dan desentralisasi ekonomi sehingga pada akhirnya menjadi kewajiban bagi daerah dalam mengelola secara efektif dan efisien.

Otonomi daerah yang dilakukan oleh Pemerintah Indonesia dimaksudkan untuk menjawab keinginan masyarakat di daerah terhadap isu utama pembangunan yaitu pembagian kekuasaan, distribusi pendapatan serta kemandirian sistem manajemen (Paul et al., 2012).

Undang - undang Nomor 33 tahun 2004 tentang Perimbangan Keuangan Pemerintah Pusat dan Pemerintah Daerah mengatur tentang desentralisasi yang merupakan alat untuk meningkatkan pelayanan publik dan kesejahteraan sosial dengan membagi fungsi, tugas, dan wewenang antar tingkat daerah.

Kebijakan desentralisasi fiskal dilakukan oleh Pemerintah Pusat terhadap Pemerintah Daerah untuk mengatasi masalah kurangnya pendapatan, mengatasi eksternalitas dan redistribusi pendapatan daerahnya (Suwandi \& Warokka, 2013).

Dalam melihat tugas pemerintah daerah dalam melaksanakan otonomi daerah dapat dilihat dari bagaimana daerah mengelola keuangan yang

* Fakultas Ekonomi dan Bisnis, Universitas Bhayangkara Jakarta Raya 
tercantum dalam Anggaran Pendapatan dan Belanja Daearh (APBD). APBD merupakan instrument utama bagi daerah dalam menentukan besaran pendapatan serta pengeluaran bagi daerah sehingga bisa digunakan untuk proses perencanaan pembangunan (Woestho et al., 2020).

Menurut (Sari et al., 2021) hal utama dalam melaksanakan otonomi daerah terletak pada tingkat kemampuan daerah dalam mengelola keuangannya yang mempunyai tingkat ketergantungan kecil kepada pemerintah pusat yang pada akhirnya diharapkan pendapatan daerah menjadi bagian dalam mobilisasi dana.

Sementara tingkat kemandirian daerah tercermin dari kemandirian keuangan daerah dalam mengelola pendapatan asli daerah (PAD) terhadap APBD. PAD merupakan salah satu sumber pendapatan utama bagi daerah dimana hal ini mengindikasikan daerah memanfaatkan potensi secara optimal.

Keberhasilan daerah dalam menjalankan pengelolaan keuangan daerah dapat dilihat dari bagaimana daerah dapat menanggulangi kemiskinan di wilayah tersebut. Hal ini menandakan bahwa daerah mampu secara efektif dan efisien dalam melaksanakan pembangunan daerahnya sehingga dapat meningkatkan kesejahteraan masyarakat. Gambar 1.

Persentase Penduduk Miskin Kabupaten Bogor Tahun 2010 - 2019

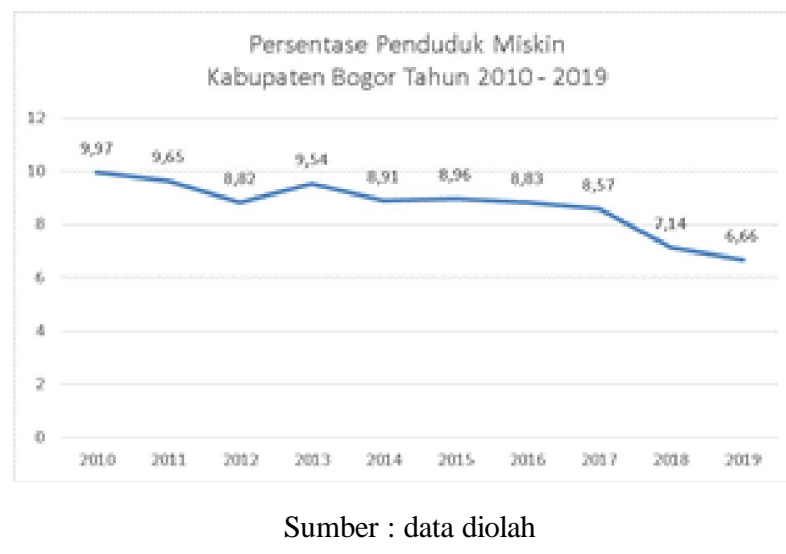

Dari data di atas, dapat diketahui penduduk miskin di Kabupaten Bogor tahun 2010 hingga tahun 2019 secara rata - rata mengalami penurunan sebesar $8,71 \%$.

Penelitian dilakukan untuk melihat keuangan Kabupaten Bogor yang mempunyai peranan dalam mengatasi permasalahan kemiskinan di Kabupaten Bogor.

\section{TINJAUAN TEORI}

Otonomi daerah diselenggarakan dengan memperhatikan prinsip demokrasi, mengajak serta peran masyarakat, pemerataan dan keadilan serta melihat potensi dan keanekaragaman daerah. Otonomi daerah telah diatur dalam Undang - Undang Nomor 23 Tahun 2014 tentang Pemerintahan Daerah dimana otonomi daerah adalah hak masyarakat daerah untuk mengatur serta mengelola daerahnya sendiri dengan mengembangkan potensi dan sumber daya daerah.

Diselenggarakannya otonomi daerah dilakukan untuk mendorong pemberdayaan masyarakat, menumbuhkan kreativitas melalui peningkatan peran serta masyarakat.

Sementara, desentralisasi merupakan penyerahan wewenang pemerintahan oleh pemerintah pusat kepada pemerintah daerah sehingga pemerintah daerah mampu mengatur dan mengurus rumah tangga yang telah diserahkan.

\section{Desentralisasi Fiskal}

Desentralisasi fiskal merupakan instrument untuk mencapai tujuan bernegara yaitu dengan memberikan pelayanan publik yang baik melalui proses pengambilan keputusan yang demokratis.

Desentralisasi terwujud melalui pelimpahan wewenang kepada tingkat pemerintahan daerah dalam hal melakukan pembelanjaan, kewenangan untuk memungut pendapatan asli daerah. Peningkatan pendapatan asli daerah merupakan salah satu cara dalam meningkatkan kemampuan keuangan pemerintah daerah dalam membiayai belanja rutin serta pembangunan di daerahnya.

Menurut (Royda \& Riana, 2019) desentralisasi fiskal merupakan pelimpahan wewenang dari pemerintah pusat kepada pemerintah daerah untuk pengambilan keputusan dan pengelolaan fiskal.

Desentralisasi fiskal melihat seberapa besar pemerintah daerah bergantung kepada pemerintah pusat dalam membiayai pembangunan sehingga untuk menilainya dibutuhkan ukuran yang disebut sebagai kemandirian keuangan daerah dan kemampuan keuangan daerah.

\section{Kemandirian Keuangan Daerah}

Menurut (Prakoso et al., 2019) pola hubungan antara pemerintah pusat dengan pemerintah daerah ditandai dengan kemandirian keuangan daerah dalam membiayai pembangunan dan pelaksanaan pemerintahan. 
Dengan kata lain kemandirian keuangan daerah melihat kemampuan pemerintah daerah dalam membiayai kegiatan pemerintahan, pembangunan di daerahnya serta pelayanan kepada masyarakat terutama yang telah membayar pajak dan retribusi.

Kemandirian keuangan daerah menggambarkan bagaimana partisipasi dari masyarakat dalam proses pembangunan daerah. Dimana semakin tinggi tingkat kemandirian keuangan daerah, berarti semakin tinggi partisipasi masyarakat dalam membayar pajak dan retribusi.yang merupakan bagian dari pendapatan asli daerah.

Tabel 1.

Pola Hubungan Tingkat Kemandirian dan Kemampuan Keuangan Daerah

\begin{tabular}{|c|c|c|}
\hline $\begin{array}{c}\text { Kemampuan } \\
\text { Keuangan }\end{array}$ & $\begin{array}{c}\text { Rasio } \\
\text { Kemandirian }\end{array}$ & $\begin{array}{c}\text { Pola } \\
\text { Hubungan }\end{array}$ \\
\hline Rendah sekali & $0-25$ & Instruktif \\
\hline Rendah & $25-50$ & Konsultatif \\
\hline Sedang & $50-75$ & Partisipatif \\
\hline Tinggi & $75-100$ & Delegatif \\
\hline
\end{tabular}

Sumber : (Royda \& Riana, 2019)

\section{Kemampuan Keuangan Daerah}

Kriteria penting dalam mengetahui kemampuan daerah dalam mengatur dan melaksanakan rumah tangga dalam bidang keuangan yaitu dengan melihat posisi keuangan daerahnya.

Sehubungan dengan pentingnya posisi keuangan tersebut, keuangan daerah sebagai salah satu indikator untuk mengetahui kemampuan keuangan daerah dalam mengatur dan mengurus rumah tangganya sendiri.

Sebagai pedoman, dapat diketahui pola hubungan kemampuan keuangan daerah dari sisi pendapatan asli daerah.

Tabel 2.

Skala Interval Derajat Desentralisasi Fiskal

\begin{tabular}{|c|c|}
\hline Persentase & $\begin{array}{c}\text { Kemampuan } \\
\text { Keuangan Daerah }\end{array}$ \\
\hline $0,00-10,00$ & Sangat kurang \\
\hline $10,01-20,00$ & Kurang \\
\hline $20,01-30,00$ & Cukup \\
\hline $30,01-40,00$ & Sedang \\
\hline $40,01-50,01$ & Baik \\
\hline$>50,01$ & Sangat baik \\
\hline
\end{tabular}

Sumber : (Royda \& Riana, 2019)

\section{METODE PENELITIAN}

Ruang lingkup dalam penelitian ini adalah tingkat kemandirian dan kemampuang keuangan daerah dengan melihat persentase penduduk miskin di Kabupaten Bogor tahun 2000 hingga tahun 2019.
Populasi yang digunakan adalah laporan realisasi anggaran Kabupaten Bogor dan persentase penduduk miskin pada periode tahun 2000 - 2019. Sementara sampel adalah bagian terkecil dari laporan realiassi anggaran yaitu pendapatan asli daerah, dana perimbangan serta total pendapatan daerah serta persentase penduduk miskin.

Penelitian yang dilakukan dengan analisis deskriptif kuantitatif dan analisis regresi linier berganda. Analisis deskriptif melihat rasio kemampuan keuangan daerah dan kemandirian keuangan daerah dimana kedua rasio tersebut dapat diketahui dengan rumus sebagai berikut.

1. Rasio Kemandirian Keuangan Daerah, merupakan tingkat kemampuan daerah dalam membiayai sendiri kegiatan pemerintahan, pembangunan dan pelayanan kepada masyarakat terutama kepada masyarakat yang telah membayar pajak dan retribusi sebagai sumber pendapatan yang diperlukan daerah

Rasio Kemandirian Keuangan Daerah

$$
\text { DOF }=\frac{\text { Pendapatan Asli Daerah }}{\text { Bantuan Pemerintah Pusat } / \text { Provinsi }} \times 100 \%
$$

2. Rasio Kemampuan Keuangan Daerah, merupakan kemampuan pemerintah daerah dalam rangka meningkatkan pendapatan asli daerah guna membiayai pembangunan.

Rasio kemampuan keuangan daerah

$$
\text { DDF }=\frac{\text { Pendapatan Asli Daerah }}{\text { Total Pendapatan Daerah }} \times 100 \%
$$

Sedangkan analisis regresi linier berganda dilakukan untuk melihat bagaimana pola hubungan antara variable kemandirian keuangan daerah dan kemampuan keuangan daerah terhadap variable persentase penduduk miskin di Kabupaten Bogor. Sehingga persamaan untuk regresi linier berganda dapat ditulis sebagai berikut:

$$
P P M=\alpha+b 1 D O F+b 2 D D F+e i t
$$

Dimana :

PPM $=$ Persentase Penduduk Miskin

DDF $=$ Derajat Desentralisasi Fiskal

DOF $=$ Derajat Otonomi Fiskal

á = konstanta

b1,b2 = koefisien

eit $=$ variable pengganggu 


\section{HASIL PENELITIAN DAN PEMBAHASAN}

Analisis Kemandirian Keuangan Daerah

Kemandirian keuangan daerah menggambarkan pola hubungan antara pendapatan asli daerah terhadap dana perimbangan yang terdiri atas dana bagi hasil, dana alokasi umum, dana alokasi khusus serta dana perimbangan.

Rasio derajat otonomi fiskal melihat bagaimana pemerintah daerah mempunyai ketergantungan terhadap pemerintah pusat atau pemerintah provinsi. Tabel 3.

Rasio Derajat Otonomi Fiskal

\begin{tabular}{|c|c|c|c|}
\hline Tahun & $\begin{array}{c}\text { Pendapatan } \\
\text { Asli Daerah }\end{array}$ & $\begin{array}{c}\text { Dana } \\
\text { Perimbangan }\end{array}$ & $\begin{array}{c}\text { Derajat } \\
\text { Otonomi } \\
\text { Fiskal }\end{array}$ \\
\hline $\mathbf{2 0 0 0}$ & 5.618 .477 & 18.968 .869 & $3,26 \%$ \\
\hline $\mathbf{2 0 0 1}$ & 4.062 .740 & 98.506 .390 & $4,12 \%$ \\
\hline $\mathbf{2 0 0 2}$ & 4.876 .360 & 152.562 .520 & $3,20 \%$ \\
\hline $\mathbf{2 0 0 3}$ & 4.587 .690 & 160.361 .420 & $2,86 \%$ \\
\hline $\mathbf{2 0 0 4}$ & 5.183 .920 & 169.992 .920 & $3,05 \%$ \\
\hline $\mathbf{2 0 0 5}$ & 6.190 .270 & 192.943 .480 & $3,21 \%$ \\
\hline $\mathbf{2 0 0 6}$ & 8.949 .580 & 300.141 .160 & $2,98 \%$ \\
\hline $\mathbf{2 0 0 7}$ & 11.823 .222 & 357.157 .966 & $3,31 \%$ \\
\hline $\mathbf{2 0 0 8}$ & 10.774 .687 & 402.666 .789 & $2,68 \%$ \\
\hline $\mathbf{2 0 0 9}$ & 13.203 .000 & 407.996 .000 & $3,24 \%$ \\
\hline $\mathbf{2 0 1 0}$ & 13.317 .007 & 392.108 .162 & $3,40 \%$ \\
\hline $\mathbf{2 0 1 1}$ & 12.481 .649 & 443.070 .850 & $2,82 \%$ \\
\hline $\mathbf{2 0 1 2}$ & 10.989 .179 & 528.943 .116 & $2,08 \%$ \\
\hline $\mathbf{2 0 1 3}$ & 16.617 .581 & 599.354 .219 & $2,77 \%$ \\
\hline $\mathbf{2 0 1 4}$ & 46.032 .160 & 637.516 .657 & $7,22 \%$ \\
\hline $\mathbf{2 0 1 5}$ & 61.267 .873 & 788.961 .672 & $7,77 \%$ \\
\hline $\mathbf{2 0 1 6}$ & 77.638 .677 & 970.730 .908 & $8,00 \%$ \\
\hline $\mathbf{2 0 1 7}$ & 97.930 .246 & 870.000 .480 & $11,26 \%$ \\
\hline $\mathbf{2 0 1 8}$ & 91.994 .774 & 941.044 .363 & $9,78 \%$ \\
\hline $\mathbf{2 0 1 9}$ & 140.833 .400 & 1.049 .790 .705 & $13,42 \%$ \\
\hline
\end{tabular}

Sumber : data diolah

Tabel tiga merupakan hasil dari pendapatan asli daerah terhadap dana perimbangan pada Kabupaten Bogor tahun 2000 - 2019.

Dari data tersebut, dapat diketahui jika selama rentang tahun $2000-2019$, nilai rasio derajat otonomi fiskal berada pada rentang $0 \%$ sampai dengan $25 \%$ sehingga dapat disimpulkan bahwa kemampuan keuangan Kabupaten Bogor rendah sekali dengan pola hubungan instruktif.

Hal ini menandakan bahwa Kabupaten Bogor dalam melaksanakan otonomi daerah masih sangat rendah sekali, dimana peranan pemerintah pusat dalam pelaksanaan pembangunan daerah masih dominan dibandingkan dengan pendapatan asli daerah yang diperoleh dari pajak dan retribusi daerah.

\section{Analisis Kemampuan Keuangan Daerah}

Kemampuan keuangan daerah melihat kemampuan daerah dengan memperhatikan nilai dari pendapatan asli daerah terhadap total pendapatan daerah. Rasio derajat desentralisasi fiskal, dapat diketahui dari tabel berikut :

Tabel 4.

Rasio Derajat Desentralisasi Fiskal

\begin{tabular}{|c|c|c|c|}
\hline Tahun & $\begin{array}{c}\text { Pendapatan } \\
\text { Asli Daerah }\end{array}$ & $\begin{array}{c}\text { Total } \\
\text { Penerimaan } \\
\text { Daerah }\end{array}$ & $\begin{array}{c}\text { Derajat } \\
\text { Desentralisasi } \\
\text { Fiskal }\end{array}$ \\
\hline $\mathbf{2 0 0 0}$ & 56.184 .779 & 255.776 .768 & $21,97 \%$ \\
\hline $\mathbf{2 0 0 1}$ & 100.680 .640 & 700.151 .360 & $14,38 \%$ \\
\hline $\mathbf{2 0 0 2}$ & 123.310 .170 & 943.760 .190 & $13,07 \%$ \\
\hline $\mathbf{2 0 0 3}$ & 148.921 .780 & 845.677 .870 & $17,61 \%$ \\
\hline $\mathbf{2 0 0 4}$ & 166.260 .110 & 991.691 .770 & $16,77 \%$ \\
\hline $\mathbf{2 0 0 5}$ & 199.424 .940 & 1.087 .081 .930 & $18,34 \%$ \\
\hline $\mathbf{2 0 0 6}$ & 230.103 .980 & 1.350 .725 .670 & $17,04 \%$ \\
\hline $\mathbf{2 0 0 7}$ & 265.371 .324 & 1.624 .534 .557 & $16,34 \%$ \\
\hline $\mathbf{2 0 0 8}$ & 307.634 .448 & 1.866 .522 .130 & $16,48 \%$ \\
\hline $\mathbf{2 0 0 9}$ & 337.903 .884 & 2.178 .137 .511 & $15,51 \%$ \\
\hline $\mathbf{2 0 1 0}$ & 399.263 .956 & 2.511 .474 .972 & $15,90 \%$ \\
\hline $\mathbf{2 0 1 1}$ & 685.121 .399 & 3.451 .755 .115 & $19,85 \%$ \\
\hline $\mathbf{2 0 1 2}$ & 1.048 .230 .704 & 3.954 .087 .602 & $26,51 \%$ \\
\hline $\mathbf{2 0 1 3}$ & 1.261 .034 .564 & 4.572 .332 .366 & $27,58 \%$ \\
\hline $\mathbf{2 0 1 4}$ & 1.712 .937 .376 & 5.378 .093 .139 & $31,85 \%$ \\
\hline $\mathbf{2 0 1 5}$ & 2.002 .209 .819 & 6.032 .847 .734 & $33,19 \%$ \\
\hline $\mathbf{2 0 1 6}$ & 2.292 .175 .674 & 5.973 .280 .685 & $38,37 \%$ \\
\hline $\mathbf{2 0 1 7}$ & 3.041 .872 .447 & 6.975 .053 .078 & $43,61 \%$ \\
\hline $\mathbf{2 0 1 8}$ & 2.794 .660 .740 & 7.300 .485 .379 & $38,28 \%$ \\
\hline $\mathbf{2 0 1 9}$ & 3.161 .165 .915 & 8.137 .989 .873 & $38,84 \%$ \\
\hline
\end{tabular}

Sumber : data diolah

Tabel empat merupakan rasio derajat desentralisasi fiskal yang merupakan perbandingan antara pendapatan asli daerah terhadap total pendapatan daerah Kabupaten Bogor tahun 2000 2019.

Secara rata - rata antara tahun 2000 - 2019, hasil kemampuan keuangan daerah berada pada angka $24,07 \%$ sehingga dapat dikatakan kemampuan keuangan daerah Kabupaten Bogor dalam pelaksanaan pembangunan daerahnya dikategorikan cukup. 
Penerimaan daerah yang terdiri dari pendapatan asli daerah, pendapatan transfer dan lain - lain pendapatan yang sah. Hasil kemampuan keuangan daerah dikategorikan cukup berarti ada besaran pendapatan yang diterima oleh Kabupaten Bogor di luar dari dana perimbangan yang tinggi yaitu dari pajak dan retribusi.

\section{Uji Asumsi Klasik}

Uji asumsi klasik merupakan pengujian yang dilakukan karena merupakan syarat yang harus dilakukan pada setiap uji regresi linier ordinary least square (OLS). Hal ini perlu dilakukan agar hasil regresi linier tidak menjadi "bias"

Uji asumsi klasik yang dilakukan dalam penelitian ini yaitu uji normalitas, uji heterokedastisitas, uji multikolinieritas dan uji autokorelasi.

\section{Uji Normalitas}

Uji normalitas untuk menguji apakah nilai residual yang telah distandarisasi pada model regresi berdistribusi normal atau tidak. Cara melakukan uji normalitas dapat dilakukan dengan pendekatan analisis grafik normal probability Plot. Pada pendekatan ini nilai residual terdistribusi secara normal apabila garis (titik-titik) yang menggambarkan data sesungguhnya akan mengikuti atau merapat ke garis diagonalnya.

Uji normalitas pada penelitian ini menggunakan pendekatan uji Jarque-Bera, pengujian normalitas dilakukan dengan menggunakan data residual. Hipotesis nol menyatakan error berdistribusi normal, sedangkan hipotesis alternatif menyatakan error tidak berdistribusi normal. Untuk pengambilan keputusan terhadap hipotesis, dapat dibandingkan antara nilai probabilitas dari uji Jarque-Bera dan tingkat signifikansi yang digunakan. Berikut aturan pengambilan keputusan terhadap hipotesis.

Jika nilai probabilitas $\geq \alpha$, H0 diterima dan $\mathrm{H} 1$ ditolak

Jika nilai probabilitas $>\alpha, \mathrm{H} 0$ ditolak dan $\mathrm{H} 1$ diterima

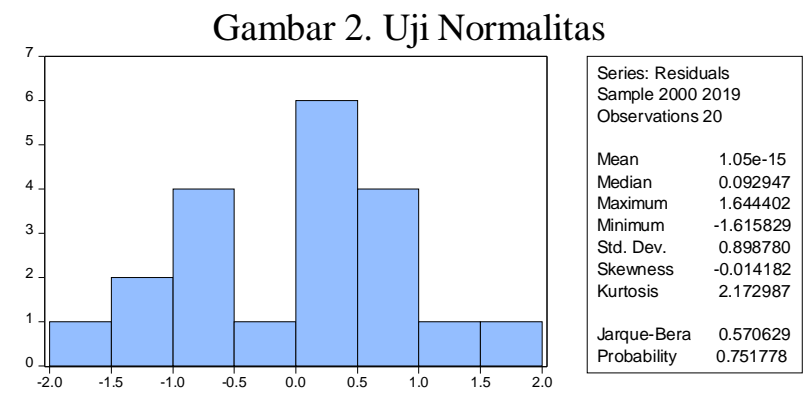

Dari hasil uji normalitas, dapat diketahui bahwa nilai Jarque-Bera Probability sebesar 0,75 atau lebih besar dari tingkat signifikansi sebesar 0,05 . Sehingga dapat dikatakan data yang ada dalam penelitian ini normal.

\section{Uji Heteroskedastisitas}

Uji heteroskedastisitas digunakan untuk mengetahui ada atau tidaknya penyimpangan asumsi klasik. Heteroskedastisitas yaitu adanya ketidaksamaan varian dari residual untuk semua pengamatan pada model regresi.

Prasyarat yang harus terpenuhi dalam model regresi adalah tidak adanya gejala heteroskedastisitas. Jika nilai prob nya $<0,05$ maka terjadi gejala heteroskedastisitas dalam model penelitian sedangkan jika nilai prob $>0,05$ maka tidak terjadi gejala heteroskedastisitas dalam model penelitian.

Tabel 5.

Uji Heteroskedastisitas

Heteroskedasticity Test: Breusch-Pagan-Godfrey

\begin{tabular}{lccc}
\hline \hline F-statistic & 0.502 & Prob. F(2,17) & 0.613 \\
Obs*R-squared & 1.118 & Prob. Chi-Square(2) & 0.572 \\
Scaled explained & & & \\
SS & 0.473 & Prob. Chi-Square(2) & 0.789 \\
\hline \hline
\end{tabular}

Sumber : data diolah

Hasil pengujian heteroskedastisitas dengan menggunakan model Breusch-Pagan, diperoleh nilai Prob.Chi-Square sebesar 0,572. Nilai ini berada diatas nilai probabilitas sebesar 0,05 , sehingga tidak terjadi gejala heteroskedastisitas.

\section{Uji Multikolinieritas}

Uji multikolinearitas bertujuan untuk menguji apakah model regresi terbentuk adanya korelasi tinggi atau sempurna antar variabel bebas (independen). Jika ditemukan ada hubungan korelasi yang tinggi antar variabel bebas maka dapat dinyatakan adanya gejala multikorlinear pada penelitian.

Nilai korelasi yang dapat ditoleransi dalam uji multikolinearitas adalah 70 persen atau 80 persen $(0,7$ atau 0,8 ).

Tabel 6.

Uji Multikolinieritas

\begin{tabular}{|c|c|c|}
\hline & DDF & DOF \\
\hline \hline DDF & 1.000000 & 0.754185 \\
\hline DOF & 0.754185 & 1.000000 \\
\hline
\end{tabular}

Sumber : data diolah 
Dari uji multikolinieritas dapat dilihat nilai toleransi sebesar 0,75 atau kurang dari 80\%, sehingga dapat dikatakan tidak terjadi gejala multikolinieritas.

\section{Uji Autokorelasi}

Uji autokolerasi merupakan kolerasi yang terjadi antara residual pada satu pengamatan dengan pengamatan lain pada model regresi. Autokorelasi dapat diketahui melalui Uji Breusch-Godfrey, dimana jika nilai prob $<0,05$ maka terjadi gejala autokorelasi sedangkan jika nilai prob $>0,05$ maka tidak terjadi gejala autokorelasi

\section{Tabel 7.}

Uji Autokorelasi

Breusch-Godfrey Serial Correlation LM Test:

\begin{tabular}{llll}
\hline \hline F-statistic & 2.384812 & Prob. F(2,15) & 0.1261 \\
Obs*R-squared & 4.825205 & Prob. Chi-Square(2) & 0.0896 \\
\hline \hline
\end{tabular}

Dari hasil pengujian autokorelasi, diperoleh nilai Prob. Chi-Square sebesar 0,0896. Hal ini dapat dikatakan bahwa tidak terjadi gejala autokorelasi pada pengamatan dalam penelitian ini.

\section{Analisis Regresi Linier Berganda}

Analisis regresi linier berganda digunakan untuk melihat dari dua variable yaitu kemandirian keuangan daerah dan kemampuan keuangan daerah faktor mana yang mempengaruhi persentase penduduk miskin.

Salah satu kunci keberhasilan suatu daerah dalam melaksanakan pembangunan di daerahnya dinilai dari keberhasilan pemerintah daerah dalam mengentaskan kemiskinan.

Uji analisis simultan (Uji F) melihat bagaimana pengaruh dari variable kemandirian keuangan daerah dan kemampuan keuangan daerah terhadap persentase penduduk miskin.

Dengan menggunakan taraf keyakinan 95\% (á = $5 \%$ ), dengan $\mathrm{df}=20$. Berdasarkan uji $\mathrm{F}$, nilai $\mathrm{F}$ Statistik sebesar 40,42 lebih besar dari nilai F kritis (Ftabel) pada á $=5 \%$, df $=20$ yaitu sebesar 3,55. Hal ini berarti seluruh variabel bebas yaitu kemandirian keuangan daerah dan kemampuan keuangan daerah dalam model mempengaruhi secara nyata terhadap variabel terikat yaitu persentase penduduk miskin dengan tingkat keyakinan $95 \%$. Signifikansi kedua variabel bebas tersebut dapat ditunjukkan pula oleh nilai $\mathrm{F}=0,000<0,05$ (nilai á $=$ 5\%) (hasil pada tabel 5).
Tabel 8.

Analisis Regresi Linier

Dependent Variable: PPM

Method: Least Squares

Date: 04/07/21 Time: 19:48

Sample: 20002019

Included observations: 20

\begin{tabular}{lrlrl}
\hline \hline \multicolumn{1}{c}{ Variable } & Coefficient & Std. Error & t-Statistic & Prob. \\
\hline \hline C & 11.14249 & 1.139994 & 9.774166 & 0.0000 \\
DOF & 0.295532 & 0.125043 & 2.363451 & 0.0303 \\
DDF & -0.171805 & 0.044425 & -3.867305 & 0.0012 \\
\hline \hline & & & & \\
R-squared & 0.827033 & Mean dependent var & 10.60850 \\
Adjusted R-squared & 0.806684 & S.D. dependent var & 2.161085 \\
S.E. of regression & 0.950180 & Akaike info criterion & 2.873149 \\
Sum squared resid & 15.34830 & Schwarz criterion & 3.022509 \\
Log likelihood & -25.73149 & Hannan-Quinn criter. & 2.902306 \\
F-statistic & 40.64234 & Durbin-Watson stat & 1.048033 \\
Prob(F-statistic) & 0.000000 & & \\
\hline \hline
\end{tabular}

Sumber : data diolah

Selanjutnya adalah uji analisis parsial (Uji t), Uji t merupakan uji statistic yang bertujuan untuk melihat pengaruh variable bebas secara individual (parsial) terhadap variabel terikat. Syarat untuk mengetahui variabel bebas mempunyai pengaruh terhadap variabel terikat dapat diketahui jika :

- Jika Prob. $>\alpha(5 \%)$, maka H0 diterima

- Jika Prob. $<\alpha(5 \%)$, maka tolak H0

Dari tabel 5, dapat diketahui bahwa dapat diketahui nilai Prob. < á (5\%), yang berarti variabel kemandirian keuangan daerah dan kemampuan keuangan daerah mempunyai pengaruh terhadap variabel dependen yaitu persentase penduduk miskin. Dari tabel di atas, juga dapat diketahui persamaan regresi

$$
P P M=11,14+0,295 D O F-0,171 D D F
$$

Hasil persamaan regresi tersebut, dapat dijelaskan sebagai berikut :

a. $\quad$ Nilai á $=11,14$ menunjukkan bahwa apabila kondisi kemampuan keuangan daerah dan kemandirian keuangan daerah tidak mengalami perubahan atau tetap, maka persentase penduduk miskin Kabupaten Bogor berubah sebesar 11,14.

b. Nilai DOF sebesar 0,295 menunjukkan setiap kenaikan rasio kemandirian keuangan daerah sebesar $1 \%$ maka akan merubah persentase penduduk miskin sebesar 0,295 dengan asumsi variabel lain tetap. 
c. Nilai DDF sebesar -0,171 menunjukkan setiap kenaikan rasio kemampuan keuangan daerah sebesar 1\% maka akan merubah persentase penduduk miskin senilai -0,171 dengan asumsi variabel lain tetap.

Sementara hasil koefisien determinasi menunjukkan seberapa besar kemampuan model dalam menerangkan variabel dependen secara statistik dengan nilai koefisien determinasi (R2) sebesar 0,806 . Hal ini berarti $80,6 \%$ persentase penduduk miskin di Kabupaten Bogor dapat dijelaskan oleh variabel kemandirian keuangan daerah dan kemampuan keuangan daerah, sementara 19,4\% dijelaskan oleh variabel lain diluar model.

\section{KESIMPULAN DAN SARAN Kesimpulan}

Derajat otonomi fiskal pada Kabupaten Bogor dari tahun 2000 hingga tahun 2019 berada pada rentang $0 \%$ sampai dengan $25 \%$, hal ini dapat disimpulkan bahwa sehingga dapat disimpulkan bahwa kemampuan keuangan Kabupaten Bogor rendah sekali dengan pola hubungan instruktif.

Hal ini menandakan bahwa Kabupaten Bogor dalam melaksanakan otonomi daerah masih sangat rendah sekali, dimana peranan pemerintah pusat dalam pelaksanaan pembangunan daerah masih dominan dibandingkan dengan pendapatan asli daerah yang diperoleh dari pajak dan retribusi daerah.

Sementara derajat desentralisasi fiskal mempunyai nilai rata - rata $24,07 \%$, sehingga dapat dikatakan kemampuan keuangan daerah Kabupaten Bogor dalam pelaksanaan pembangunan daerahnya dikategorikan cukup.

Untuk analisis regresi linier berganda, baik kemandirian keuangan daerah dan kemampuan keuangan daerah mempunyai pengaruh terhadap persentase penduduk miskin.

Kemandirian keuangan daerah mempunyai pengaruh positif sebesar 0,295 yang berarti dalam pelaksanaan otonomi daerah $29,5 \%$ telah mampu untuk mengurangi penduduk miskin di Kabupaten Bogor.

Sementara nilai kemampuan keuangan daerah mempunyai pengaruh negative sebesar 0,171 yang berarti dalam melaksanakan otonomi daerah, pemerintah Kabupaten Bogor sudah bisa mengurangi penduduk miskin di wilayahnya.

Seperti yang telah diketahui, pembangunan yang dilakukan oleh pemerintah daerah pada dasarnya adalah untuk mensejahterakan masyarakat yang berada di daerahnya. Sehingga hal ini menjadi isu utama bagi daerah, dimana setiap pendapatan daerah harus mampu untuk membiayai penanganan kemiskinan di wilayah tersebut.

\section{Saran}

Dari hasil penelitian yang telah dilakukan, ada beberapa saran yang dapat diberikan:

1. Pemerintah Kabupaten Bogor dapat memperluas lagi basis penerimaan pajak dan retribusinya.

2. Perlu ada pengawasan anggaran yang lebih ketat, sehingga setiap pendapatan mampu digunakan dalam rangka mensejahterakan masyarakat yang pada akhirnya dapat mengurangi penduduk miskin di wilayah tersebut.

3. Dalam hal ketergantungan terhadap pemerintah pusat dan pemerintah provinsi, Kabupaten Bogor dapat membuka investasi di wilayah negara dengan memberikan kepastian hukum yang tepat sehingga iklim investasi dapat berjalan dengan baik.

\section{DAFTAR PUSTAKA}

Kamaroellah, R. A. (2017). Analisis Tingkat Kemampuan Keuangan Daerah Dalam Mendukung Pelaksanaan Otonomi Daerah. Nuansa: Jurnal Penelitian Ilmu Sosial Dan Keagamaan Islam, 14(1), 123. Https:// Doi.Org/10.19105/Nuansa.V14i1.1316

Paul, J., Renyaan, A., Ubud, S., \& Idrus, M. S. (2012). Effect Of Fiscal Autonomy And Economic Growth On Local Financial Performance ( A Study On Local Government Of Papua Province ). 1(1), 16-21.

Prakoso, J. A., Islami, F. S., \& Sugiharti, R. R. (2019). Analisis Kemampuan Dan Kemandirian Keuangan Daerah Terhadap Pertumbuhan Ekonomi Dan Kemiskinan Di Jawa Tengah. Jurnal Rep (Riset Ekonomi Pembangunan), 4(1), 87-100. Https://Doi.Org/10.31002/ Rep.V4i1.1344

Royda, \& Riana, D. (2019). Analisis Kemandirian Dan Kemampuan Keuangan Daerah Serta Pengaruhnya Terhadap Pertumbuhan Ekonomi Kabupaten/Kota Di Provinsi Sumatera Selatan. Jurnal Akuntansi Dan Manajemen, 14(2), 50-64. 
Sari, R. K., Woestho, C., \& Handayani, M. (2021). Analisis Kemampuan Keuangan Daerah Pada Daerah Tertinggal Di Provinsi Sulawesi Tengah. Jurnal Kajian Ilmiah, 21(1), 45-54. Https:// Doi.Org/10.31599/Jki.V21i1.324

Suwandi, \& Warokka, A. (2013). Fiscal Decentralization And Special Local Autonomy: Evidence From An Emerging Market. The Journal Of Southeast Asian Research, 2013, 1-14. Https://Doi.Org/10.5171/2013.554057
Woestho, C., Sulistyowati, A., \& Sari, R. K. (2020). Analisis Kemampuan Dan Kemandirian Keuangan Daerah Serta Pengaruhnya Terhadap Pertumbuhan Ekonomi Di Kabupaten Jeneponto. Jurnal Ekonomi Pembangunan Stie Muhammadiyah Palopo, 6(2), 91-100. 